\begin{tabular}{|c|c|c|c|c|c|c|}
\hline \multirow{4}{*}{ Impact Factor: } & ISRA (India) & $=3.117$ & SIS (USA) & $=0.912$ & ICV (Poland) & $=6.630$ \\
\hline & ISI (Dubai, UAE & $=0.829$ & РИНЦ (Russia & $=\mathbf{0 . 1 5 6}$ & PIF (India) & $=1.940$ \\
\hline & GIF (Australia) & $=0.564$ & ESJI (KZ) & $=8.716$ & IBI (India) & $=4.260$ \\
\hline & JIF & $=1.500$ & SJIF (Morocco & $=\mathbf{5 . 6 6 7}$ & OAJI (USA) & $=0.350$ \\
\hline
\end{tabular}

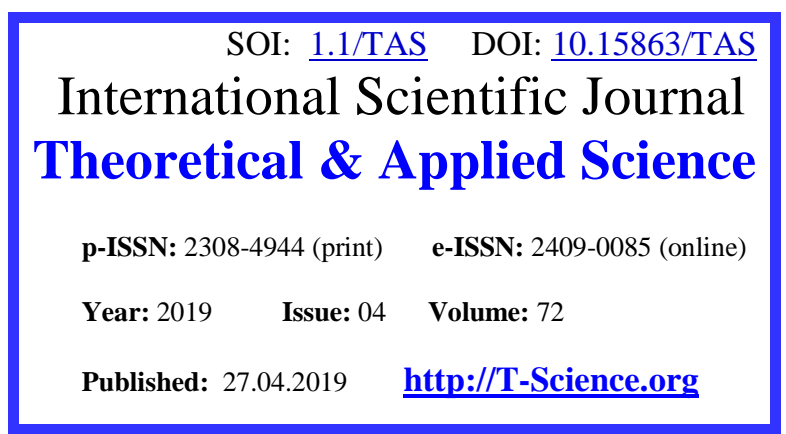

SECTION 9. Chemistry and chemical technology
QR - Issue

QR - Article
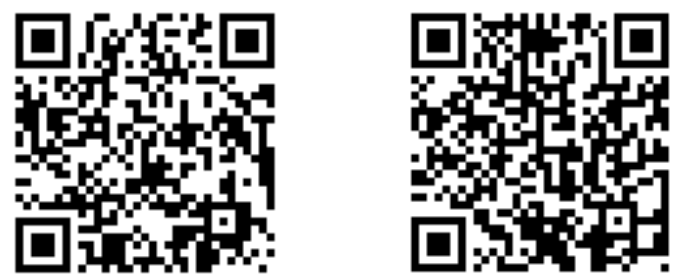

Adilya Aliyoldash Mahmudova

PhD in Chemistry, Leading Scientific Researcher Azerbaijan State Pedagogical University adila.mahmudova@gmail.com

Gulnar Hajimammad Mammadova aspirant, Institute of Chemistry of Additives, Azerbaijan National Academy of Sciences, Azerbaijan memmedova1987@gmail.com

Sabir Sahib Babayev

$\mathrm{PhD}$ in Chemistry, Leadinq Scientific Researcher, Institute of Chemistry of Additives, Azerbaijan National Academy of Sciences, Azerbaijan aki05@mail.ru

Sabir Ahmad Mammadov Doctor in Chemistry, Professor, Head of Laboratory, Institute of Chemistry of Additives, Azerbaijan National Academy of Sciences, Azerbaijan mamedov.39@inbox.ru

Lala Fahraddin Zeynalova aspirant, Institute of Chemistry of Additives, Azerbaijan National Academy of Sciences, Azerbaijan zlali@inbox.ru

\title{
STUDY OF REACTIVITY OF HYDROXYL GROUP IN 1-ARYLOXYNONANOL-2
}

Abstract: The reactivity of hydroxyl group in 1-aryloxynonanol-2 which was obtained by the interaction of heptyloxirane with substituted phenols in the presence of sodium metal was studied. The content of aromatic radical intensifies protonization of hydroxyl group. As a result in the reaction of 1-aryloxynonanol-2 with $\alpha$-chloro ethers (chloro methoxyethyl) yields of ethers with dimethylaniline make 75-85\%. The reaction of obtaining amides and thioamides with isocyanates and isothiocyanates also goes easily. The position of a substituent in phenol fragment has a little effect on the reactivity of hydroxyl group.

Key words: aryloxynonanol-2, $\alpha$-chloro ethers, urethane, arylisocyanates, arylisothicyanates, antimicrobial property.

Language: English

Citation: Mahmudova, A. A., Mammadova, G. H., Babayev, S. S., Mammadov, S. A., \& Zeynalova, L. F. (2019). Study of reactivity of hydroxyl group in 1-aryloxynonanol-2. ISJ Theoretical \& Applied Science, 04 (72), 371-376.

Soi: http://s-o-i.org/1.1/TAS-04-72-47 Doi: crossef https://dx.doi.org/10.15863/TAS.2019.04.72.47 


\begin{tabular}{|c|c|c|c|c|c|c|}
\hline \multirow{4}{*}{ Impact Factor: } & ISRA (India) & $=3.117$ & SIS (USA) & $=0.912$ & ICV (Poland) & $=6.630$ \\
\hline & ISI (Dubai, UAE & $=0.829$ & РИНЦ (Russia & $=\mathbf{0 . 1 5 6}$ & PIF (India) & $=1.940$ \\
\hline & GIF (Australia) & $=0.564$ & ESJI (KZ) & $=8.716$ & IBI (India) & $=4.260$ \\
\hline & JIF & $=1.500$ & SJIF (Morocco & $=5.667$ & OAJI (USA) & $=0.350$ \\
\hline
\end{tabular}

\section{INTRODUCTION}

1,2-dioxyethers alkanes have been widely used in medicine and have high antibacterial and fungicide properties [1,2]. Apart from ethers the content of amino groups gives the compounds antiarrhythmic and analgesic properties [3], but in the presence of pyrrolidine fragment ethers are antagonists of calcium receptors [4]. Considering their valuable properties, the method of obtaining aminocyclohexyl ethers has been developed [5].

\section{EXPERIMENTAL}

IR-spectra of obtained compounds were registered at spectrometer "Nicolet IS-10, NMR $\mathrm{H}^{1}$ spectra were registered at spectrophotometer "Tesla467 " with a frequency of $80 \mathrm{MHz}$. The purity of the compounds was determined by Gas-Liquid Chromatography analysis using LKhM-8MD chromatograph with a flame ionization detector. Temperature of a column is $200{ }^{\circ} \mathrm{C}$. Temperature of an evaporator is $260{ }^{\circ} \mathrm{C}$. Helium is used as a carrier gas.

Synthesis of 1-phenoxy-2-nonanol (I). $66.9 \mathrm{~g}$ ( $0.3 \mathrm{~mol})$ of 1-bromium-2-nonanol was added drop by drop into the mixture of $28.2 \mathrm{~g}(0.3 \mathrm{~mol})$ of phenol and $30 \mathrm{~g}$ of $40 \%$ aqueous solution of $\mathrm{NaOH}$ at $80-85$ ${ }^{0} \mathrm{C}$ and vigorous mixing. During mixing the mixture was heated up to $80-85{ }^{\circ} \mathrm{C}$ for 5 hours. Obtained ether was extracted with benzene. Benzene solution was washed out with water till neutral reaction, dried, benzene was distilled, and then the residue was distilled under vacuum. $48.7 \mathrm{~g}(66 \%)$ of product was obtained.

The compounds II and III were synthesized similarly. Their characteristics are given in the table 1 .

Synthesis of 1-(2-methylphenoxy)-2ethoxymethoxynonane (IV). $10 \mathrm{~g}(0.04 \mathrm{~mol})$ of 1-(2methylphenolxy)-nonanol-2 and $6.05 \mathrm{~g}(0.051 \mathrm{~mol})$ of freshly-distilled dimethylaniline were dissolved in 70 $\mathrm{ml}$ of anhydrous benzene. At room temperature and mixing for $30 \mathrm{~min} 4.7 \mathrm{~g}(0.5 \mathrm{~mol})$ of freshly-distilled $\alpha$-chloromethylethyl ether dissolved in $30 \mathrm{ml}$ of anhydrous benzene was added. Reaction mass was mixed at room temperature for an hour, and then at 55$60{ }^{0} \mathrm{C}$ for 3-4 hours. It was cooled, washed out with $5 \%$ solution of $\mathrm{HCl}$ and then with water till neutral reaction. Benzene solution was dried $\mathrm{Na}_{2} \mathrm{SO}_{4}$, benzene was distilled, and then the residue was distilled under vacuum by collecting fractions boiling at $146-148{ }^{0} \mathrm{C} / 3 \mathrm{mmHg}$. $8.2 \mathrm{~g}(70 \%)$ of product was obtained. Compounds V and VII were synthesized similarly.
Synthesis of 1-(2-methylphenoxy)-2acetoxynonane (VIII). $10 \mathrm{~g} \quad(0.04 \mathrm{~mol})$ 1-(2methylphenoxy)-nonanol-2 (compound I) and $6.1 \mathrm{~g}$ $(0.05 \mathrm{~mol})$ of dimethylaniline were dissolved $60 \mathrm{ml}$ of anhydrous benzene. During mixing $3.93 \mathrm{~g}(0.05 \mathrm{~mol})$ of chloro acetyl was added into the solution drop by drop. At $45-50{ }^{0} \mathrm{C}$ and mixing reaction mass was heated for 3-4 hours. Then it was cooled, washed out with $5 \%$ solution of $\mathrm{HCl}$ and water till neutral reaction. Benzene solution was dried, benzene was distilled, and then the residue was distilled under vacuum by collecting fractions boiling at 134-136 ${ }^{0} \mathrm{C} / 1 \mathrm{mmHg}$. $8.2 \mathrm{~g}(70 \%)$ of product was obtained. Compounds IX and X were obtained similarly. Their physical and chemical properties are given in the table 1.

Synthesis of 1-phenoxy-2-Nphenylurethanenonane $(\mathbf{X}) .10 \mathrm{~g}(0.04 \mathrm{~mol})$ of 1 phenoxy-2-nonanol was dissolved in $40 \mathrm{~mol}$ of anhydrous benzene. At $80-85{ }^{\circ} \mathrm{C}$ and mixing $5.95 \mathrm{~g}$ (0.05 mol) of phenylisocyanate was added drop by drop inti the solution of $20 \mathrm{ml}$ anhydrous benzene. The mixture was mixed at $80-85^{\circ} \mathrm{C}$ for $3-4$ hours. Then it was cooled till room temperature, $25 \mathrm{ml}$ of anhydrous hexane was added. Precipitated crystals were filtered and then recrystallized from the mixture of hexanebenzene (3:1). $9.7 \mathrm{~g}(68.1 \%)$ of product was obtained. Compounds XI and XIII were synthesized similarly.

In NMR ${ }^{1} \mathrm{H}$-spectrum (Fig.1) of 1-phenoxy-2-Nphenylcarbamidenonane (compound XI) protons $\mathrm{CH}_{3}$ and $\left(\mathrm{CH}_{2}\right)_{5}$ appear in unresolved form at 0.8-1.4 ppm, but protons $\mathrm{CH}_{2}-\mathrm{Ar}, \mathrm{CH}$ and $\mathrm{CH}_{2}-\mathrm{O}$ are observed in the form of doublet at 5,3 ppm.

\section{RESULTS AND DISCUSSION}

Considering high bioactivity of ethers of carboxylic acids and aromatic phenols containing active functional groups, currently strengthened studies on the development of more rational methods of their obtaining are carried out.

The dynamic kinematic determination of $\alpha, \alpha-$ disubstituted carboxylic ethers catalyzed with $\mathrm{N}$ heterocyclic carbenes was conducted by interesterification reaction of alcohols [7] by using organic compounds of actinide metals as catalysts with asymmetric tandem esterification reaction with proton transfer between aldehydes and alcohols. The developed method of esterification is suitable for a wide range of applications of substrates in the synthesis of different ethers. Reactivity of chlorine atom in alkanols under the impact of hydroxyl group in $\beta$-position was studied. It was found [8] that the reaction of $\mathrm{M}$-methylphenol with 1-bromium-2hydroxyoctan-ol-2 goes with high yield.

Studies on the reaction of 4-chlor-2-butanol or chlorpropanol with oxalic acid also showed reactivity of hydroxyl group [9]. 


\begin{tabular}{|c|c|c|c|c|c|c|}
\hline \multirow{4}{*}{ Impact Factor: } & ISRA (India) & $=3.117$ & SIS (USA) & $=0.912$ & ICV (Poland) & $=6.630$ \\
\hline & ISI (Dubai, UAE & $=0.829$ & РИНЦ (Russia & $=\mathbf{0 . 1 5 6}$ & PIF (India) & $=1.940$ \\
\hline & GIF (Australia) & $=0.564$ & ESJI (KZ) & $=8.716$ & IBI (India) & $=4.260$ \\
\hline & JIF & $=1.500$ & SJIF (Morocco & $=5.667$ & OAJI (USA) & $=0.350$ \\
\hline
\end{tabular}

The content of chlorine atom in 1-position and 3position in propanol propylthiogroups activate hydroxyl group and due to this esterification goes smoothly and the yields are very high. Moreover, 1aryloxyalkylpropanols easily react with isocyanates or thioisocyanates forming carbamates and thiocarbamates $[9,10]$.

1-(m-tolyloxy)-octanol-2 was synthesized by the reaction of $\mathrm{m}$-cresol with 1-bromium-2-octanol. Reactivity of hydroxyl group in the reactions with $\alpha$ chlormethylpropyl ether, acetylchloride and during condensation with aromatic isocyanates and thioisocyanates was studied. All synthesized carbamates and thiocarbamates have effective bactericide properties against staphylococcus, candida, typhoid fever and penicillin [11].

It was established [12] that the content of carbamate groups in 1- (N,N-diethyldithiocarbamate)2-propanol does not block the reaction with arylisocyanates and isothiocyanates. On the contrary, yields of carbamates and thiocarbamates increase. Synthesized amides have high bactericide properties.

We have proposed the research on the reaction of aryloxynonal-2 with substituted phenols. 1-bromiumnonanol-2 and heptyloxirane were obtained by the known method:

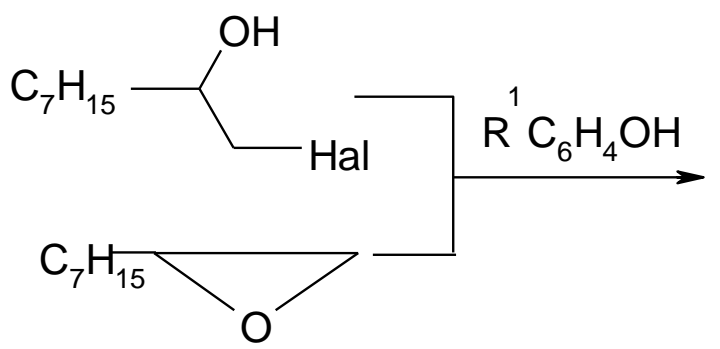<smiles>[R]OCC(O)CCCC</smiles>

Scheme 1

$\mathrm{R}^{1}=\mathrm{H}(\mathrm{I}) ; \mathrm{o}-\mathrm{CH}_{3}(\mathrm{II})$; m- $\mathrm{CH}_{3}$ (III); $\mathrm{p}-\mathrm{CH}_{3}$ (IV)

Due to the impact of electron acceptor aryloxyfragment hydrogen of hydroxyl group is easily substituted with $\alpha$-chlorethers forming polyethers with high yields:
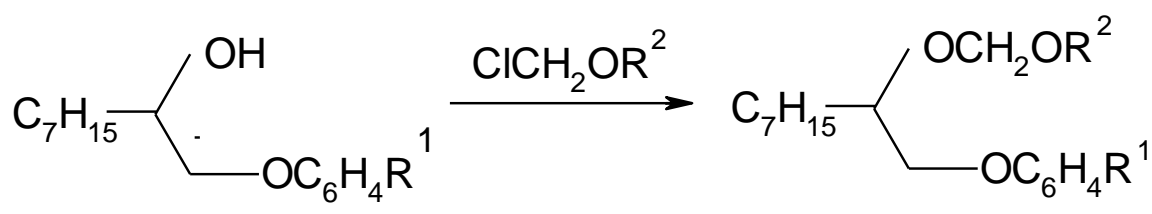

$\mathrm{R}^{1}=\mathrm{O}-\mathrm{CH}_{3}, \mathrm{R}^{2}=\mathrm{C}_{2} \mathrm{H}_{5}(\mathrm{~V}) ; \mathrm{R}^{1}=\mathrm{m}-\mathrm{CH}_{3}$

$\mathrm{R}^{2}=\mathrm{C}_{2} \mathrm{H}_{5}(\mathrm{VI}) ; \mathrm{R}^{1}=\mathrm{p}-\mathrm{CH}_{3}, \mathrm{R}^{2}=\mathrm{C}_{2} \mathrm{H}_{5}(\mathrm{VII})$;

$\mathrm{R}^{1}=\mathrm{O}-\mathrm{CH}_{3}, \mathrm{R}^{2}=\mathrm{COCH}_{3}(\mathrm{VIII}) ; \mathrm{R}^{1}=\mathrm{m}-\mathrm{CH}_{3}$,

Scheme 2

$\mathrm{R}^{2}=\mathrm{COCH}_{3}(\mathrm{IX}), \mathrm{R}^{1}=\mathrm{p}-\mathrm{CH}_{3}, \mathrm{R}^{2}=\mathrm{COCH}_{3}(\mathrm{X})$

For confirmation of hydroxyl group the synthesis of urethanes was carried out by the reaction of arylisocyanates with aryloxynonanol-2:

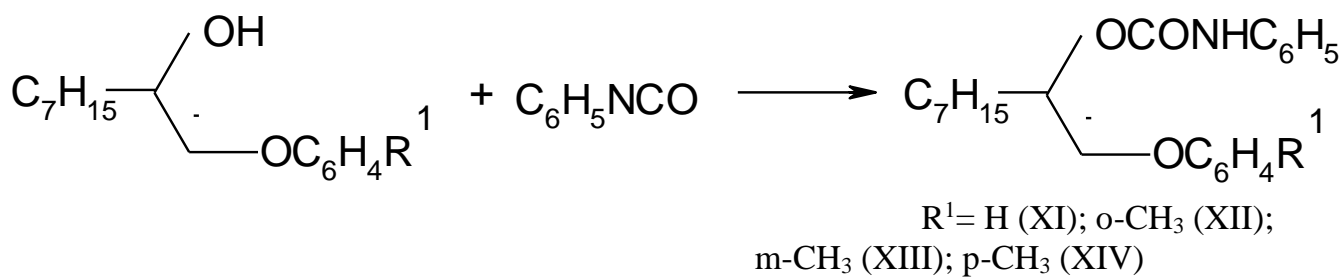

Scheme 3 


\begin{tabular}{|c|c|c|c|c|c|c|}
\hline \multirow{4}{*}{ Impact Factor: } & ISRA (India) & $=3.117$ & SIS (USA) & $=0.912$ & ICV (Poland) & $=6.630$ \\
\hline & ISI (Dubai, UAE & $=0.829$ & РИНЦ (Russia & $=0.156$ & PIF (India) & $=1.940$ \\
\hline & GIF (Australia) & $=0.564$ & ESJI (KZ) & $=8.716$ & IBI (India) & $=4.260$ \\
\hline & JIF & $=1.500$ & SJIF (Morocce & $=5.667$ & OAJI (USA) & $=0.350$ \\
\hline
\end{tabular}

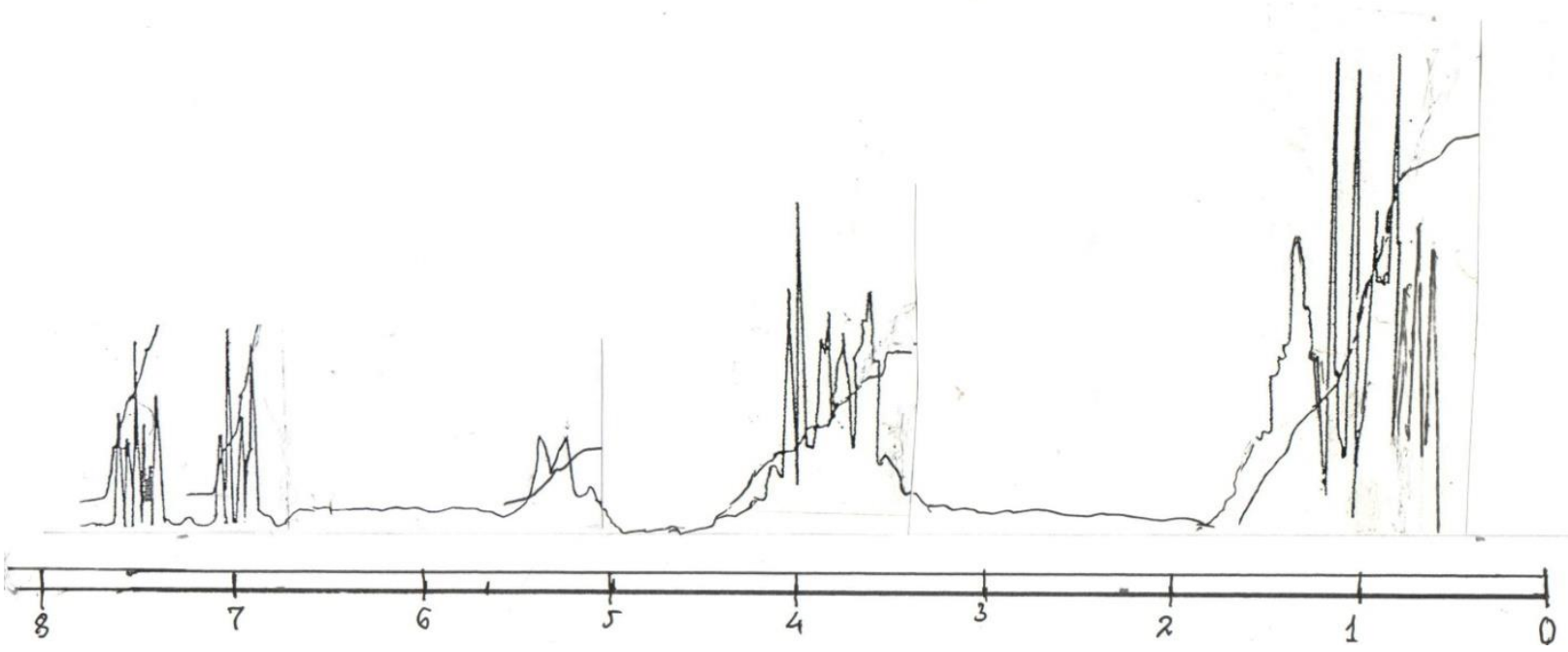

Fig.1. NMR-spectrum of 1-phenoxy-2-N-phenylcarbamidenonane (compound XI)

Aromatic ether groups containing urethane are highly effective as additives to lubricating oils. Moreover, representatives of this class of organic compounds are highly effective antimicrobial preparations.

Compounds (X - XIII) were studied as antimicrobial additives to lubricating oils (in the composition of oil M-8). The results are given in the table 2. As table shows amides (compounds X - XIII) have fungicide properties and their effectiveness does not much depend on the position of a substituent in aromatic nuclear. They are more effective than industrial fungicide.

Amides containing a substituent in p-position are more effective than the substituents in other positions.

Table 2. Antimicrobial properties of 1-oxyphenyl-2-N-phenylureido-or-thioureidononanes (X - XVII):<smiles>CCCC(COC(=O)Nc1ccccc1)OC(=O)OCC</smiles>

\begin{tabular}{|c|c|c|c|c|}
\hline \multirow{2}{*}{$\mathrm{X}$} & \multirow{2}{*}{$\mathrm{R}$} & Concentration, \% & \multicolumn{2}{c|}{ Diameter of depression zone of microorganisms, cm } \\
\cline { 4 - 5 } $\mathrm{O}$ & $\mathrm{H}$ & 0,3 & 1,8 & 2,2 \\
& & 0,5 & 2,2 & 2,8 \\
\hline $\mathrm{O}$ & $\mathrm{o}-\mathrm{CH}_{3}$ & 0,3 & 2,1 & 2,8 \\
& & 0,5 & 2,6 & 3,2 \\
\hline $\mathrm{O}$ & $\mathrm{M}-\mathrm{CH}_{3}$ & 0,3 & 1,9 & 2,8 \\
& & 0,5 & 2,7 & 3,4 \\
\hline $\mathrm{O}$ & $\Pi-\mathrm{CH}_{3}$ & 0,3 & 2,3 & 3,5 \\
& & 0,5 & 2,1 & 3,9 \\
\hline $\mathrm{S}$ & $\mathrm{H}$ & 0,3 & 2,8 & 2,1 \\
& & 0,5 & 3,2 & 2,9 \\
\hline $\mathrm{S}$ & $\mathrm{o}-\mathrm{CH}_{3}$ & 0,3 & 3,1 & 2,4 \\
& & 0,5 & 3,9 & 2,6 \\
\hline $\mathrm{S}$ & $\mathrm{M}-\mathrm{CH}_{3}$ & 0,3 & 2,9 & 2,5 \\
& & 0,5 & 3,5 & 2,8 \\
\hline $\mathrm{S}$ & $\Pi-\mathrm{CH}_{3}$ & 0,3 & 3,1 & 2,1 \\
& & 0,5 & 3,6 & 2,2 \\
\hline
\end{tabular}




\begin{tabular}{|c|c|c|c|c|c|c|}
\hline \multirow{4}{*}{ Impact Factor: } & ISRA (India) & $=3.117$ & SIS (USA) & $=0.912$ & ICV (Poland) & $=6.630$ \\
\hline & ISI (Dubai, UAE & $=0.829$ & РИНЦ (Russia & $=0.156$ & PIF (India) & $=1.940$ \\
\hline & GIF (Australia) & $=0.564$ & ESJI (KZ) & $=8.716$ & IBI (India) & $=4.260$ \\
\hline & JIF & $=1.500$ & SJIF (Morocco & $=5.667$ & OAJI (USA) & $=0.350$ \\
\hline
\end{tabular}

Table 1. Physical and chemical properties of synthesized compounds (I-XIV)

\begin{tabular}{|c|c|c|c|c|c|c|c|c|c|c|}
\hline \multirow{3}{*}{$\begin{array}{l}\text { №№ } \\
\text { Comp. }\end{array}$} & \multirow{3}{*}{$\begin{array}{l}\text { Yield } \\
\%\end{array}$} & \multirow{3}{*}{$\begin{array}{l}\mathrm{T}_{\text {boil. }} / \mathrm{mm} \\
\mathrm{Hg} \text { of } \\
\mathrm{T}_{\text {melt., }} \\
{ }^{0} \mathrm{C}\end{array}$} & \multirow{3}{*}{$\mathrm{n}_{\mathrm{D}}^{20}$} & \multirow{3}{*}{$\mathrm{d}_{4}{ }^{20}$} & \multicolumn{2}{|c|}{$\mathrm{MR}_{\mathrm{D}}$} & \multirow{3}{*}{$\begin{array}{l}\text { Chemical } \\
\text { formula }\end{array}$} & \multicolumn{3}{|c|}{ Analysis, \% } \\
\hline & & & & & \multirow[b]{2}{*}{ Found } & \multirow{2}{*}{ Calcul. } & & $\mathrm{C}$ & $\mathrm{H}$ & $\mathrm{N}$ \\
\hline & & & & & & & & \multicolumn{3}{|c|}{ Found /Calculated } \\
\hline I & 66,9 & $\begin{array}{c}170- \\
171 / 1 \\
35-36\end{array}$ & - & - & - & - & $\mathrm{C}_{15} \mathrm{H}_{24} \mathrm{O}_{2}$ & $\frac{78,18}{78,27}$ & $\frac{10,05}{10,16}$ & - \\
\hline II & 66,5 & $\begin{array}{c}173- \\
174 / 1\end{array}$ & 1,4922 & 0,9532 & 76,13 & 76,221 & $\mathrm{C}_{16} \mathrm{H}_{26} \mathrm{O}_{2}$ & $\frac{76,67}{76,75}$ & $\frac{10,29}{10,46}$ & - \\
\hline III & 63,7 & $\begin{array}{c}178- \\
179 / 1 \\
39-40\end{array}$ & - & - & - & - & $\mathrm{C}_{16} \mathrm{H}_{26} \mathrm{O}_{2}$ & $\frac{76,70}{76,75}$ & $\frac{10,29}{10,46}$ & - \\
\hline IV & 68,8 & $\begin{array}{c}179- \\
180 / 1 \\
49-50\end{array}$ & - & - & - & - & $\mathrm{C}_{16} \mathrm{H}_{26} \mathrm{O}_{2}$ & $\frac{76,91}{76,75}$ & $\frac{10,22}{10,46}$ & - \\
\hline $\mathrm{V}$ & 70,3 & $\begin{array}{c}144- \\
145 / 3\end{array}$ & 1,4702 & 1,9384 & 91,74 & 92,12 & $\mathrm{C}_{19} \mathrm{H}_{3} \mathrm{O}_{3}$ & $\frac{73,8}{73,98}$ & $\frac{10,31}{10,45}$ & - \\
\hline VI & 70,3 & $\begin{array}{c}146- \\
147 / 3\end{array}$ & 1,4724 & 1,9392 & 92,16 & 91,9 & $\mathrm{C}_{19} \mathrm{H}_{32} \mathrm{O}_{3}$ & $\frac{73,8}{73,98}$ & $\frac{10,33}{10,45}$ & - \\
\hline VII & 70,9 & $\begin{array}{c}143- \\
144 / 3\end{array}$ & 1,4922 & 0,9532 & 76,13 & 76,221 & $\mathrm{C}_{16} \mathrm{H}_{26} \mathrm{O}_{2}$ & $\frac{73,8}{73,98}$ & $\frac{10,33}{10,45}$ & - \\
\hline VIII & 73,5 & $\begin{array}{c}134- \\
135 / 1\end{array}$ & 1,4758 & 0,9695 & 84,94 & 85,12 & $\mathrm{C}_{18} \mathrm{H}_{28} \mathrm{O}_{3}$ & $\frac{73,7}{73,98}$ & $\frac{10,31}{9,63}$ & - \\
\hline IX & 74,6 & $\begin{array}{c}133- \\
134 / 1\end{array}$ & 1,4750 & 0,9692 & 84,96 & 85,12 & $\mathrm{C}_{18} \mathrm{H}_{28} \mathrm{O}_{3}$ & $\frac{73,60}{73,98}$ & $\frac{9,41}{9,63}$ & - \\
\hline $\mathrm{X}$ & 77,8 & $\begin{array}{l}135- \\
136 / 1\end{array}$ & 1,4754 & 1,9681 & 84,89 & 85,12 & $\mathrm{C}_{18} \mathrm{H}_{28} \mathrm{O}_{3}$ & $\frac{74,08}{73,98}$ & $\frac{9.85}{9,63}$ & - \\
\hline XI & 71,2 & $55-56$ & - & - & - & - & $\mathrm{C}_{22} \mathrm{H}_{29} \mathrm{O}_{3}$ & $\frac{74,18}{74,36}$ & $\frac{8,01}{8,17}$ & $\frac{8,85}{3,94}$ \\
\hline XII & 70,8 & $45-46$ & - & - & - & - & $\begin{array}{c}\mathrm{C}_{23} \mathrm{H}_{31} \\
\mathrm{NO}_{3}\end{array}$ & $\frac{74,62}{74,79}$ & $\frac{8,31}{8,4}$ & $\frac{3,61}{3,79}$ \\
\hline XIII & 71,9 & $48-49$ & - & - & - & - & $\begin{array}{c}\mathrm{C}_{23} \mathrm{H}_{31} \\
\mathrm{NO}_{3}\end{array}$ & $\frac{74,65}{74,79}$ & $\frac{8,18}{8,4}$ & $\frac{3,67}{3,79}$ \\
\hline XIV & 76,1 & $46-47$ & - & - & - & - & $\begin{array}{c}\mathrm{C}_{23} \mathrm{H}_{31} \\
\mathrm{NO}_{3}\end{array}$ & $\frac{74,65}{74,79}$ & $\frac{8,18}{8,4}$ & $\frac{3,67}{3,79}$ \\
\hline
\end{tabular}

\section{References:}

1. Kimpe, N. D., Doeleris, M., \& Contreras, J. (1996). Tetrahedron Lett., V.37, pp. 3171-3176.

2. Thery, O., \& Etienne, N. (2007). Tetrahedron Lett., pp. 1546-1550.

3. Schenone, S. O. (2000). Farmaco, V. 55, №6, pp. 495-498.
4. Cavai, A. V., \& Mikkilineni, A. B. (2005). Bioorg.Med.Chem., V.15, №24, pp. 5478-5482.

5. Bernard, A., Michael, J. A., \& Walker, R. A. (n.d.). Patent 6174879 USA.

6. Chen, X., Feng, J., Xu, J., \& Mou, C. (2016). J..Am. Chem. Soc., 138, № 23, pp. 7212-7215. 


\begin{tabular}{|c|c|c|c|c|c|c|}
\hline \multirow{4}{*}{ Impact Factor: } & ISRA (India) & $=3.117$ & SIS (USA) & $=0.912$ & ICV (Poland) & $=6.630$ \\
\hline & ISI (Dubai, UAE & $=0.829$ & РИНЦ (Russia & $=\mathbf{0 . 1 5 6}$ & PIF (India) & $=1.940$ \\
\hline & GIF (Australia) & $=0.564$ & ESJI (KZ) & $=8.716$ & IBI (India) & $=4.260$ \\
\hline & JIF & $=1.500$ & SJIF (Morocco & $=5.667$ & OAJI (USA) & $=0.350$ \\
\hline
\end{tabular}

7. Liu, H., \& Eisen, M. S. (2017). Orqanomettallics, 36, № 8, pp. 1461-1464.

8. Hasanov, V. S., Mahmudova, A. A., Babaeva, G. V., \& Bakhshieva, I. S. (2013). AzChemJ. № 4, pp. 101-105.

9. Hasanov, V. S., Mahmudova, A. A., Babaeva, G. V., Rahimov, I. R. (2014). AzChemJ. № 1, pp. 104-108.
10. Hasanov, V. S., Mahmudova, A. A., Babaeva, G. V., Bakhshieva, U. S., \& Akperli, G. N. (2014). AzChemJ. № 3, pp. 110-115.

11. Hasanov, V. S. (2013). AzChemJ. № 4, pp. 101105.

12. Babaeva, G. V., \& Zeynalova, L. F. (2013). AzChemJ, № 3, pp. 121-124. 